\title{
POWER AND STATUS IN COETZEE'S DISGRACE
}

\author{
Maisarah \\ Universitas Pesantren Tinggi Darul Ulum \\ maisarah@fbs.unipdu.ac.id
}

\begin{abstract}
This article aims to discuss the symbols which may have direct relationship with power and status in a novel, Disgrace. The setting of this novel is in South Africa where the transition era was taken place from apartheid to democracy. In this era, power and status are becoming important issue to discuss. To emphasize the two issues in a literary work, the author uses symbols. There are many symbols that can be found in this novel. Among the symbols which exist, three of them have correlation with power and status. Those symbols are sex, dogs and one of the characters in this novel, Peter. Those three symbols will be analyzed by using Stuart Hall's theory about representation. This study comes to conclusion that the first symbol, sex, is a representation of man's power over woman. The second symbol, dog, is a representation of lower social status. The third symbol, Petrus, is a representation of changing status of Black people in South Africa
\end{abstract}

Keywords: Representations, symbol, power, status

\section{A. INTRODUCTION}

Disgrace is a novel by J. M. Coetzee, published in 1999. It won the Booker Prize. The writer was also granted the Nobel Prize in Literature four years after its publication (en.wikipedia.org, 2018). Disgrace takes place in South Africa when a transition from the apartheid era to the era of democracy occurred. However, the "taste" of Apartheid is still deeply felt in the novel.

In J.M. Coetzee's Disgrace, the author uses many kinds of Symbolism. This article will discuss the symbols that may have direct relationship with power and status. "Power is best conceptualized as control over critical resources - that is, outcome control" (Groth, 2012). Status is "prestige, respect and esteem that a party has in the eyes of others ... an index of the social worth that others ascribe to an individual or a group. Status originates externally and is rooted in the evaluations of others through statusconferral processes" (Groth, 2012).

Among the symbols that exist, three symbols, in relation with power and status, are interested to discuss. The three symbols are Sex, Dogs, and Peter. Sex has a lot of to do with how men maintain its hegemony to the women. It also represents how the society views the relationship between men and women. Dogs give much description of the status of certain level (e.g., lower class people) in the community. Petrus gives an overview of the changing status of the blacks in South Africa.

\section{B. STUART HALL'S REPRESENTATION}

According to Stuart Hall (1997) representation is a process by which meaning is formed and exchanged between a cultural member through the language use, signs and images that symbolize or represent things. Through representation, language functions as a mirror. It means that the true meaning of an object, person, idea or event is reflected through language. Basically, the reflective theory proposes that language works by merely reflecting or copying a fixed "truth" that is previously existed in the real world (Hall, 1997).

Meaning is constantly formed within language; it is the practice of representation, built through signifying. Hall (1997:16) states that:

"as described in the previous section, the "real world" itself does not convey meaning. Instead, meaning-making relies two different but related systems of representation: concepts and language. Concepts are our mental 
representations of real-world phenomena. They may be constructed from physical, material objects that we can perceive through our senses (e.g. a chair, a flower, a tangerine), or they may be abstract things that we cannot directly see, feel, or touch (e.g. love, war, culture). In our minds, we organize, cluster, arrange and classify different concepts and build complex schema to describe the relations between them".

\section{SEX AS A REPRESENTATION OF MAN'S POWER OVER WOMAN}

Sexuality becomes the major issue in Disgrace. In this novel, sexuality represents male domination over women. Sexual relationship conducted by David Lurie with various women and the rape committed by the black gang against Lucy represent the patriarchal system in society, seeing men as powerful over women.

Lurie's sex relationship with Soraya and Melanie Isaac shows how men see women in South Africa at that time. Soraya is a prostitute, and therefore is an object of sex for men. Melanie is a student, and as a female student, she becomes vulnerable to being exploited by her teacher with a sexual interest to her. The harassment experienced by Melanie made her to have a systemic anxiety during her life (Fanani, 2014).

In Disgrace sex clearly represents a symbol for power. David Lurie connects the idea of power with the body, explaining his patriarchal views towards women and sex. In this novel, David Lurie shows a very doubtful relationship with the women in his life. He had been married two women, but later divorced with them (Chapter 1). Instead of his status as a divorced man, David believes "he has solved the problem of sex rather well" (Chapter 1 ).

In the beginning of the novel, it is told that David is having sex relationship with a Muslim prostitute named Soraya. He visits her once a week for over a year. From the beginning of the novel, it is known that David grasps a conservative patriarchal viewpoint towards women. David gambles about Soraya's life, 'Soraya is not her real name' and has she 'borne a child' (Chapter 3)? He assumed that prostitution is only Soraya's part-time job and it is a result of a failure, and he wants to cash in on of this. David was grown up in a male-controlled society in South Africa that sees male social value is in higher place than that of female, especially in a postapartheid era. So anything has been done by David to Soraya is not incorrect because the malecontrolled society permits this to happen.

David's relationship with his student, Melanie, best describes his political and social values towards women. Melanie's name is interpreted as 'the dark one' by David (Chapter 18), directly showing a prejudiced social value of the white against the black. As stated above, David has grown up in the influence of the apartheid, which allows him to have an 'excuse' for the misconduct that he does to Melanie. While the patriarchal society was questionably outof-date by the time in which the novel is written (1999) the supposed post-feminist South Africa was weakened by men like David whose characters were minced by political and social agendas that gave men authority just for being men.

Sex used as a representation of power is reflected from how he chooses Melanie as the victim of his predatory lust. Actually, there is one more student besides Melanie who is also the potential to become his prey. She is Amanda. But for David chasing Melanie, a black student, is an exercise of 'power and authority'. Amanda is described as having 'wispy blonde' hair (Chapter 29), leading to the assumption she is white. David has 'no interest' (Chapter 29) in Amanda as it would almost be 'acceptable' to have sex with her. Therefore rushing Melanie will be more challenging. In general, David sees women as property and asserts his power through using the silent 'body of the women' (Chapter 10) as nothing more than a cheap adventure in which he is in full control.

Body and sexuality in Disgrace is a means to show power and authority. How sex also reflects powers is represented by the occurrence of rape done by the black gang against Lucy, a daughter of David Lurie (Chapter 11). Lucy is 'perhaps' a lesbian because she is not married and has no interest in men. The black 
rapists, as seen in this story, turn out to have an association with Petrus, a Lucy's former helper.

The rape shows how black people began to "take power" over the white people. The Rape occurred, as represented by the title of this novel, makes the main character feel disgraced.

\section{DOGS AS REPRESENTATION OF LOWER-LEVEL STATUS}

Dog is an important animal in Disgrace. It is seen particularly after David moves to the country. On a surface level, they are just seen as animals, nothing more. But when we think about them more deeply, they are not there just as animals; rather, they represent social status and personal disgrace.

In general dogs in this novel embody the statuses of different people in society. Dogs in this novel are realized as mediocre animals. Lucy, for example, once says, "I don't want to come back in another existence as a dog or a pig and have to live as dogs or pigs live under us" (Chapter 8). The representation of lower class people with dogs can also be seen when Coetzee characterizes Petrus. In the novel, he introduces himself to David as the "dog-man" (Chapter 7), he at that time certainly work for Lucy. However, as he stages an advanced social status, this changes. He anecdotes at a party held by him that he is "not any more the dog-man" (Chapter 15). This also indicates that Petrus is no longer on the same level as dogs.

Dogs are also used to characterize the personal status of one's character, in this case David Lurie. As everything gets worse for him and makes him goes deeper and deeper into shame and disgrace, his personal character becomes more like that of a dog. He compares himself to a dog that is beaten for following its sexual instincts (Chapter 11), when he talks to Lucy about his dishonor at the University. David also acts like a dog by getting down on all his hands and legs when he says sorry to Isaac, similar to a dog showing regret before its master. David holds negative view of dogs. Dogs are shameful and without agency, pride, and so forth.

As the story goes on, dogs become more linked with the people suffering from disgrace. The following example shows this tendency. This is a dialogue between Lucy and David when discussing the humiliation of how things have turned out:

"Perhaps that is what I must learn to accept. To start at ground level. With nothing. Not with nothing but. With nothing. No cards, no weapons, no property, no rights, no dignity."

"Like a dog."

"Yes, like a dog."

(chapter 22)

Dogs in this novel are animals described as destitute creature with no rights or pride. Not long after this chat, David becomes concern with one dog at the clinic suffering from a crippled leg. Towards the end of the story, David resolves to help the dog out of its depression by giving it up to Bev for deadly injection. This is also a portrayal that living in disgrace is truly more shameful than death. The existence of dogs in Disgrace drives us to mirror the humiliation and disgrace that human beings experience, even though it is described through the lives of animals.

\section{E. Petrus as a Representation OF CHANGING STATUS OF BLACK PEOPLE IN SOUTH AFRICA}

At a glance Petrus can be understood as simply a countryman, someone not significant. $\mathrm{He}$ is described as a middle-aged man as David notices: "A lined, weathered face; shrewd eyes. Forty? Fortyfive?" (Chapter 7). Petrus introduced himself to David about his job, consisting of rural obligations:

"I look after the dogs and I work in the garden. Yes...I am the gardener and the dog-man." $\mathrm{He}$ reflects for a moment. "The dog-man," he repeats, savouring the phrase. (Chapter 7)

However when we look more about him, Petrus characterizes something. It looks that Petrus doesn't like to be perceived as the "dog-man". So when the whole thing have transformed to him he later says "I am no more the dog-man" just as he begins to rejoice 
the land transfer that will make him a richer and more influential man.

The status transformation and swift change of power of black people is also well represented by Petrus' swift of status. The land transfer from Lucy, Petrus, a black people, makes him a wealthy people. He develops to be an instance of prosperous blacks in South Africa after Apartheid. Lucy not ever comes right out and states why she assists Petrus to acquire the land, and she also appears ashamed when Petrus refers to Lucy as his family's patron (Chapter 15).

Peter represents a common outlook of the black community that is unwilling to involve in businesses relating to the blacks and whites - particularly when the sufferers are the white. Throughout the acts of Lucy's rape, Petrus looks unenthusiastic to interfere in the conflict - he doesn't even want to give an opinion as to what occurred. He considers that what occurred to Lucy is just a simple criminality, a very trivial robbery.

Petrus who appears to close his eye displays his solidarity to his fellow black people. Though he is a worthy friend of Lucy, but the fact that he has the same race as the rapist makes him less concerned in arguing the problems suffered by Lucy. Furthermore, it is known that he also has a lot at risk in terms of his own family's happiness. At the time Petrus defends Pollux, he doesn't just guard for a fellow of his own race; he also looks out for a fellow of his own family

\section{CONCLUSION}

Disgrace by J. M. Coetzee is a distressing book that forces the reader to challenge the shadier side of life and manage ethical issues and the improper instincts of humanity. In J.M. Coetzee's Disgrace, the author uses a lot of Symbolism. Among the symbols that are present, three symbols, in relation with power and status, are interested to be discussed. The three symbols are Sex, Dogs, and Peter. Sex has a lot of to do with how men maintain its hegemony to the women. It also represents how the society views the relationship between men and women. Dogs give much description of the status of certain level (e.g., lower class people) in the community. Petrus gives an overview of the changing status of the blacks in South Africa.

\section{REFERENCES}

Coetzee, J. M. 1999. Disgrace. New York: Penguin. Print.

en.wikipedia.org. (2018). Retrieved January 2018, from https://en.wikipedia.org/wiki/Disgrace: https://en.wikipedia.org/wiki/Disgrace

Fanani, A. (2014). Kecemasan Dalam Cerpen An Anxious Man Karya James Lasdun. Diglossia, 5260.

Groth, A. (2012, August). http://www.businessinsider.com/steven-bladerya-ru-chen-power-and-status-research-20128/?IR=T. Retrieved January 2018, from www.businessinsider.com: http://www.businessinsider.com/steven-bladerya-ru-chen-power-and-status-research-2012$8 /$ ?IR=T

Hall, Stuart. 1997. Representation. Cultural Representations and Signifying Practices. SAGE Publication. London. 